\title{
ТOM \\ Gender and science in animation: analysis of the Anima Mundi Festival films
}

\section{Gabriela Reznik and Luisa Medeiros Massarani}

Abstract

Keywords

DOI

Introduction
We used content analysis to analyse the representation of female scientists in animated short films on gender and science, selected from the Anima Mundi Festival, over 21 annual editions. In these films, female scientists are featured as 'intelligent', 'dominant' and 'well respected', adult, white, wearing a lab coat or uniform and working in laboratories and fieldwork. We identified a reconfiguration of the gender stereotype in films in which the female character is about to gain space and visibility. We also analysed films whose sexist foundations in the relationship between scientists and their interlocutors reinforce the reproduction of sexist and heteronormative stereotypes.

Representations of science and technology; Science and technology, art and literature; Women in science

https://doi.org/10.22323/2.18020208

Submitted: 31st January 2019

Accepted: 29th March 2019

Published: 20th May 2019

For many decades, when asked to draw a scientist, children and teenagers put recurring symbols on paper: the male character gets a lab coat, glasses, a beard, and test tubes [Chambers, 1983]. Although this stereotype remains alive in the social imaginary, we noticed that new references have emerged in animated cartoons, such as Luna, from O Show da Luna (Earth to Luna!, in the English version) - a Brazilian animated series created by Célia Catunda and Kiko Mistrorigo, featured on the Discovery Kids channel — and Princess Jujuba from Hora da Aventura (Adventure Time) - an American series created by Pendleton Ward for the Cartoon Network, which are notable for the reconfiguration of gender roles [Inocêncio and Oliveira, 2015; Anibal and dos Santos, 2016; de Oliveira and Magalhães, 2017; Meneses, 2017; da Silveira Jr. and Prado, 2017].

In a historical analysis of women's representations in Brazilian cartoons, da Silveira Jr. and Prado [2017] highlight a worldwide trend in narrative construction - driven by the strengthening of feminist debates at the end of the 21st century - to break with "the archetype of the traditional, helpless princesses 
dependent on the prince, presenting them as brave women with problem-solving skills" [da Silveira Jr. and Prado, 2017, p. 131]. The authors describe that in Brazilian television Mônica in A turma de Mônica [Mônica's group] was the first prominent female character in 1963 - who became an ambassador for Unicef (United Nations Children's Fund/UN) in 2007 as an icon of defense of the rights of children and teenagers. Since then, female representation has acquired a new meaning in Brazilian productions, in dialogue with the third feminist wave - which sought to expand feminist themes to include a diverse group of women with a diverse set of identities - and with the claims for a less stereotyped representation of the female world.

Gender and science studies discussed the invisibility and the delegitimisation of women's presence in science. Evelyn Fox Keller [1978] argues that modern science would be associated with the idea of a male enterprise, oriented to the domination and control of a nature seen as passive and feminine and portrayed by metaphors of marriage and submission. The underrepresentation of women in science would be associated with the social construction of a particular definition of science - as objective, universal and neutral - and of the association of such characteristics with masculinity, as opposed to the construction of femininity as essentially linked to irrationality and emotion, and to care and nature [Keller, 1987; Citelli, 2000; Harding, 2007].

The images of women in different media reinforce culturally and socially accepted norms of the female universe, as in the accomplishment of domestic work and childcare [Steinke, 2005; da Silva Mesquita and Soares, 2008]. Duarte [2002] argues that the way the cinema deals with what is female is the result of more cultural rather than technical conventions, and highlights Kaplan's [1995] analysis that the dominant images of women in films are constructed by and for a male point of view.

In the context of scientist representations in films, female scientists are underrepresented [Long et al., 2010; Whitelegg et al., 2008; Massarani et al., 2013] and are portrayed differently from the classical stereotype of the male scientist - sometimes highlighted by their physical appearance [Chimba and Kitzinger, 2010]; or by being attractive and sexy, having a 'professional' personality, being intelligent, articulate, determined and independent, and commonly involved in love affairs [Steinke, 2005].

In this article, we refer to the concept of gender as a "constitutive element of social relations based on the perceived differences between the sexes, and gender is a first way of signifying power relations" [Scott, 1995, p. 21], including the notion of gender as the difference produced in the culture allied with concern for the situations of inequality experienced by women [Piscitelli, 2009].

This work is inserted in a broader research work on the images of science and scientists in animated short films taken from the 21 annual editions of the Anima Mundi International Animated Film Festival, in which we aim to understand symbols, elements and characteristics attributed to science and scientists in films about S\&T themes. 
Methodological approach
In this article, we analysed the animated short films of the Anima Mundi Festival dealing with gender and science themes from 1993, when the festival was first launched, to 2013. We chose to analyse Anima Mundi's productions because this is the largest animated film festival in the Americas and the second worldwide. Held annually in the cities of Rio de Janeiro and São Paulo (Brazil), it has an annual audience of about 80,000 participants and provides an overview of the Brazilian and international production of animated films, particularly the independent scene, and aims to promote animation in its plurality and diversity, valuing the inclusion of films of different nationalities and with different animation techniques, narratives and themes. Within the context of author or independent animation, the animator has more freedom to explore and invent their own means of meaning in the design of films as communication processes, creating new languages in the film industry, with short films being the main film format [Graça, 2006].

In order to select the films that constitute our corpus, we analysed the synopses of all the films exhibited at the festival during the period of our study. Then, we selected the films whose synopsis refers directly to the terms 'science', 'scientific', 'scientist', 'research', 'inventor' and 'explorer'. ${ }^{1}$ Then, we analysed the films that feature female scientists, that address gender issues and/or have sexist foundations. By using a qualitative approach in content analysis, we highlighted characteristics related to the nationality of the films, female participation in management; attributes, symbols and characteristics attributed to scientists; workplace where scientists appear and different narratives used in audiovisual productions.

The category of analysis for scientists' characteristics is based on the work of Long et al. [2010] and Steinke et al. [2011]. The study led by Long et al. [2010] aimed to identify certain traits of scientist characters in $14 \mathrm{TV}$ programmes that represent four genres (cartoon, drama, educational and comedy), suitable for the age range of 12 to 14 . On the basis of the study carried out by Calvert, Kotler et al. [2003], the authors selected certain attributes regarded as typically feminine in order to identify if the female scientist characters presented stereotyped gender characteristics such as dependent, attentive and romantic and typically masculine attributes such as independent, athletic and dominant. The authors also analysed attributes related to the desire of young people to identify themselves with the characters, considering the characteristics 'intelligent', 'considerate', 'respected' and 'violent'. Studies show that men and women identify themselves with characters who are intelligent [Hoffner, 1996; Hoffner and Buchanan, 2005], who have a socially active behavior [Calvert, Murray and Conger, 2004] and are admired [Hoffner and Buchanan, 2005]. Men still identify themselves with characters who are violent on the scene [Hoffner and Buchanan, 2005]. Long and her collaborators [2010] considered the characteristic 'respected' as an indicator of admiration and 'attentive' as an indicator of active social behavior. In this study we analysed the attributes of 'intelligent', 'dominant', 'solitary', 'respected' and 'attentive', as detailed in Table 1.

\footnotetext{
${ }^{1}$ For more details on the content analysis protocol, on the selection criteria of the films and on the complete table of films analysed in this research work, see [Reznik, 2017; Reznik, Massarani and Moreira, 2019].
} 
Table 1. Characteristics of the scientists adapted from the studies of Long et al. [2010] e Steinke et al. [2011].

\begin{tabular}{|c|l|}
\hline Intelligent & $\begin{array}{l}\text { Characters demonstrated intelligence when they made factual statements or gave } \\
\text { opinions about the cause of a certain phenomenon that has happened. When } \\
\text { they explained how a process worked; explained or used specialised terminology. } \\
\text { They gave suggestions on how to proceed in an experiment; outlined formulas or } \\
\text { inventions; or used scientific instruments or equipment to analyse a material. }\end{array}$ \\
\hline Dominant & $\begin{array}{l}\text { Characters exhibited dominance when they exercised authority or influence over } \\
\text { other characters (e.g. told or showed other characters what to do, told other char- } \\
\text { acters that they were wrong). }\end{array}$ \\
\hline Lonely & $\begin{array}{l}\text { The character was shown alone when he/she was the human being present in a } \\
\text { scene and did not appear interacting with another person; or when the narrative } \\
\text { of the film showed the character was socially isolated (e.g. the father of a family } \\
\text { who is locked in the laboratory and there is conflict with family members due to } \\
\text { the isolation). }\end{array}$ \\
\hline Respected & $\begin{array}{l}\text { The character was considered respected when another character showed respect } \\
\text { and consideration for him; when they asked the scientist's opinion or asked for } \\
\text { their advice; when the character received a prize. }\end{array}$ \\
\hline Attentive & $\begin{array}{l}\text { When the character acted to help or comfort another character; demonstrated em- } \\
\text { pathy; offered physical or psychological welcome to another character. }\end{array}$ \\
\hline
\end{tabular}

Animation films on female scientists
Of the 102 films selected from the festival's collection about science, we identified only 10 films in which female scientists appeared over the 21 years analysed (Table 2). Five short films were Brazilian productions and the others were produced in France, United States, Luxembourg, Australia and in the United Kingdom. The reduced presence of women in animation productions at the Anima Mundi Festival is not restricted to science and technology films. By analysing more than 8,000 films in 25 festival editions, including short films and feature films, advertising material, among other genres presented at the festival, Prado [2017] points out that the female participation in animated productions of Anima Mundi Festival is still low, accounting for $23 \%$ of the audiovisual productions. 







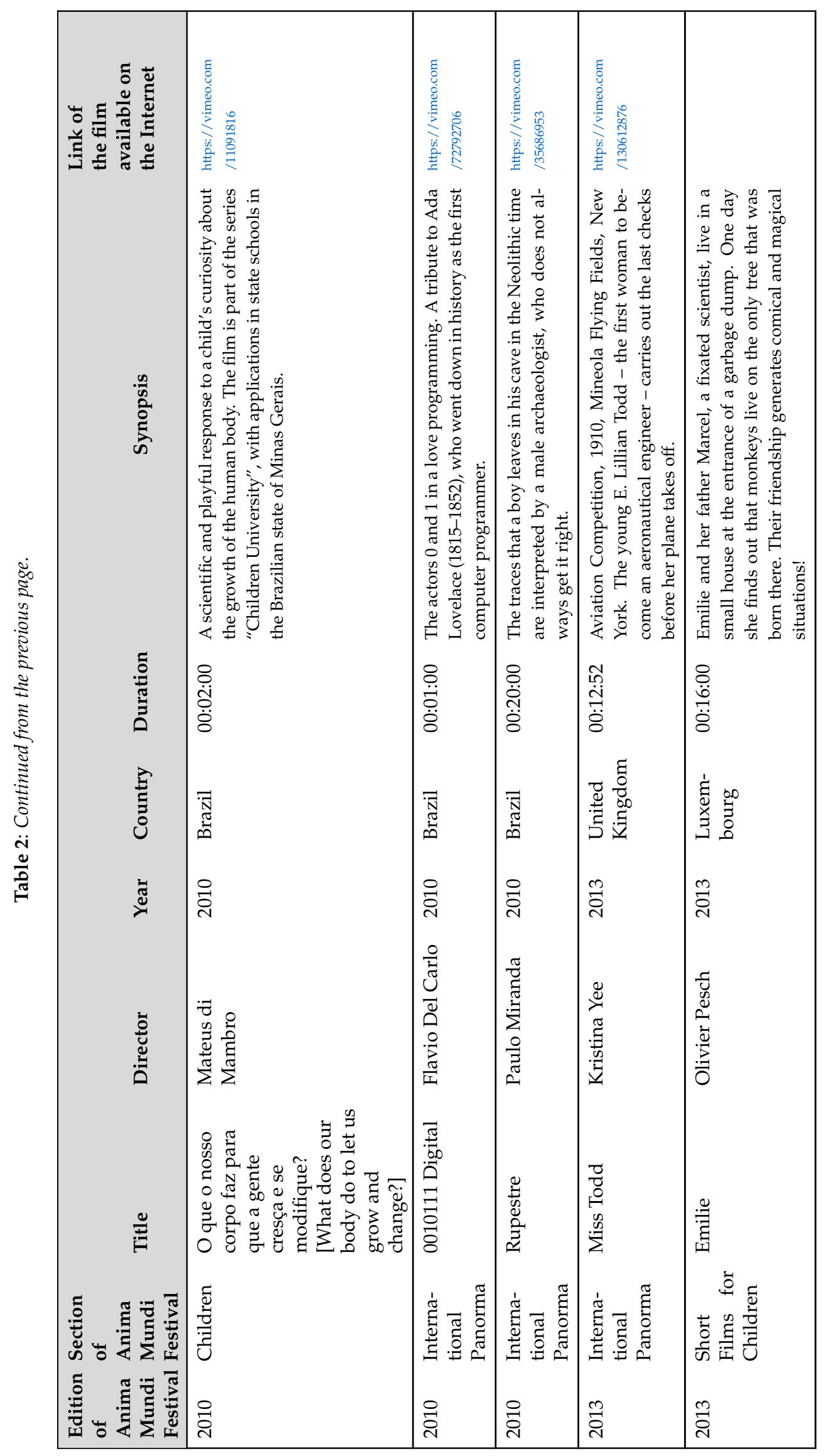


In the 10 films identified in our study, the female scientist characters are adult, white, they wear a lab coat or uniform, appear in laboratories and do fieldwork and in $50 \%$ of the films books appear in the scenario characterised as the place of women scientists. It is worth mentioning that characteristics such as 'intelligent', 'dominant' and 'respected' were associated with most of the characters, highlighting a different result from what is found in literature in regards to the representation of female scientists in films [Long et al., 2010; Steinke et al., 2011]. Considering the small number of films identified in our sample that includes female scientists, we will now summarise the films and the main characteristics attributed to them.

In Miss Todd (Kristina Yee, United Kingdom, 2013), Rocket Science (Sam Morrison, United States, 2006) and Frankenchiken (Ann-Marie Denham, Australia, 2004), the role of women in a dominant position is made problematic, for example the scientific characters face barriers for being women in a position of power. In Rocket Science, the character is a forensic scientist (Figure 1) responsible for unraveling a crime, but who, in her relationship with the police, is demoted and ridiculed for being a woman. There are lines like "Just because this scientist is a girl, it does not mean that she has to be wrong" and "Maybe I feel threatened by a woman in a position of power." Sexist foundations in scientific thinking influence public representations about science and scientists, as in the dialogue undertaken in the movie Rocket Science between the forensic scientist and the police. Similarly, Schienbinger [2001] describes the way in which Immanuel Kant referred to the Marquise du Châtelet (1706-1749), who worked in the field of physics and mathematics: "she might as well even have a beard, for perhaps that would express more obviously the mien of profundity for which she strives."



Figure 1. Image of the female scientist in Rocket Science (United States, 2006).

Frankenchiken is a thriller story in which a chick's biggest dream is to become the outdoor advertising rooster in front of his farm. In order to achieve this, it is forced to genetic experiments. Whoever performs the experiments is a female scientist who is subordinate to three men linked to the industry. As the experiments do not 
go as planned and the rooster turns into a kind of Frankenstein-rooster, the woman is verbally assaulted by her bosses. In the film 0010111 Digital (Flavio Del Carlo, Brazil, 2010), the scientist character does not appear, but the short film was made to pay tribute to Ada Lovelace (1815-1852), who went down in history as the first programmer, whose image appears towards the end of the film (Figure 2).

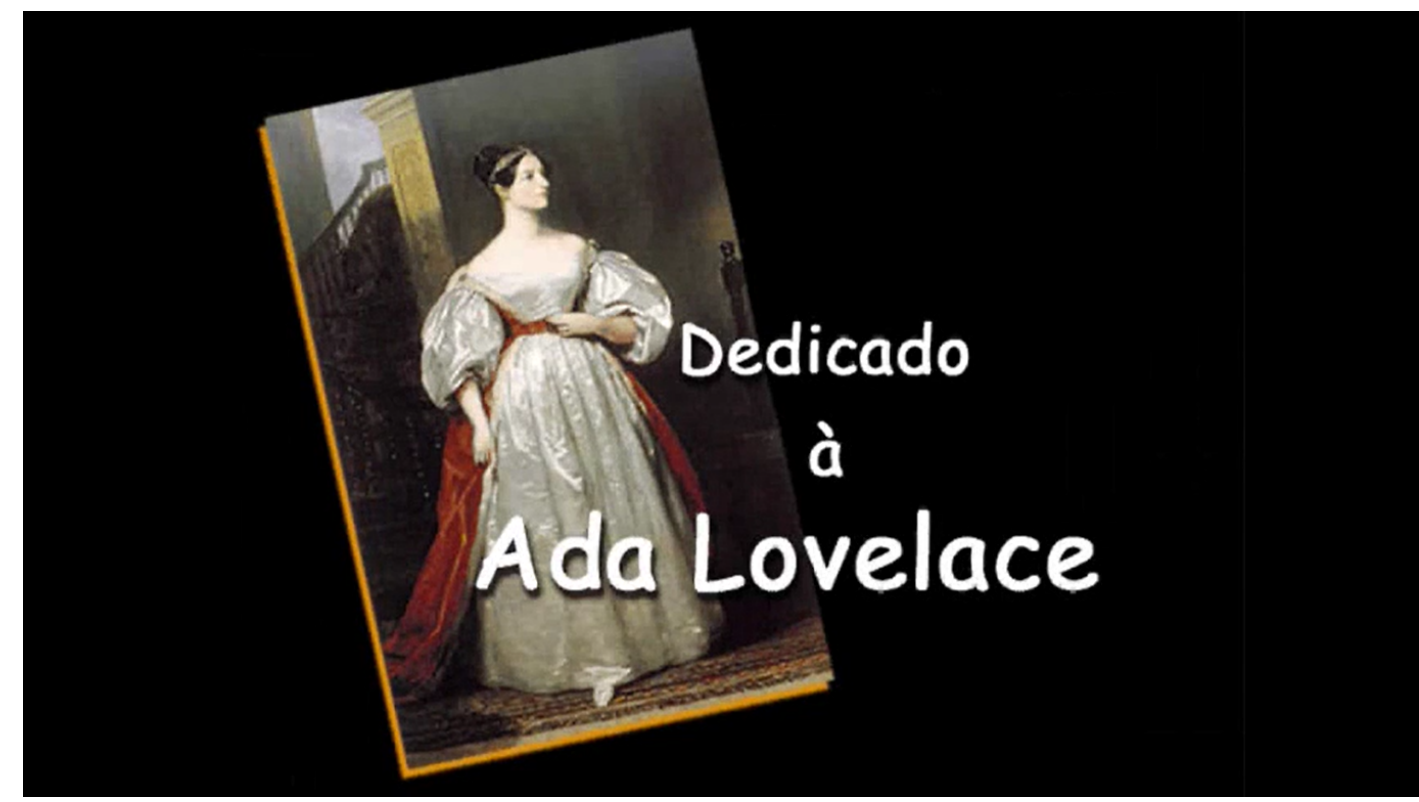

Figure 2. Scene from 0010111 Digital (Brazil, 2010).

In O que o nosso corpo faz para que a gente cresça e se modifique? [What does our body do for us to grow and change?] (Brazil, 2010), by Mateus di Mambro, produced by the Children University, the scientist says that she became a researcher because of her curiosity as a child. From a toy trunk, she takes out a magnifying glass and then shows up in a lab coat, wearing glasses, at the university on a classroom blackboard. The film is part of a series of episodes of the extension project of the Institute of Biological Sciences (ICB), in collaboration with the School of Fine Arts, the Communication Centre and the Scientific Dissemination Board of the Federal University of Minas Gerais. The project develops activities with children aged 9 to 11 in state schools near the city of Belo Horizonte, in which it collects questions on topics related to the human body and the environment. On the basis of the questions/answers and the interaction between the project team, children, researchers and other professionals, texts with or without illustrations, short radio programmes and animation short films are produced and are available in Portuguese and English on Vimeo. ${ }^{2}$

In Stopmo (Adel Benabdallah, Brice Boisset, Vincent Secher, Romain Hua, Anouk Eyraud, France, 2008), the scientist character is a female archeologist who digs out an animation studio buried in snow and relives scenes from old films. The character is a courageous, determined and pioneering woman with a detail of the Batman symbol in her work uniform (Figure 3).

The film Emilie (Oliver Pesch; Luxembourg, 2012) blends symbols of the stereotype of the scientist - lab coat, glasses, beard, social isolation, above average

\footnotetext{
${ }^{2}$ Available on: https://vimeo.com/unicriancas.
} 


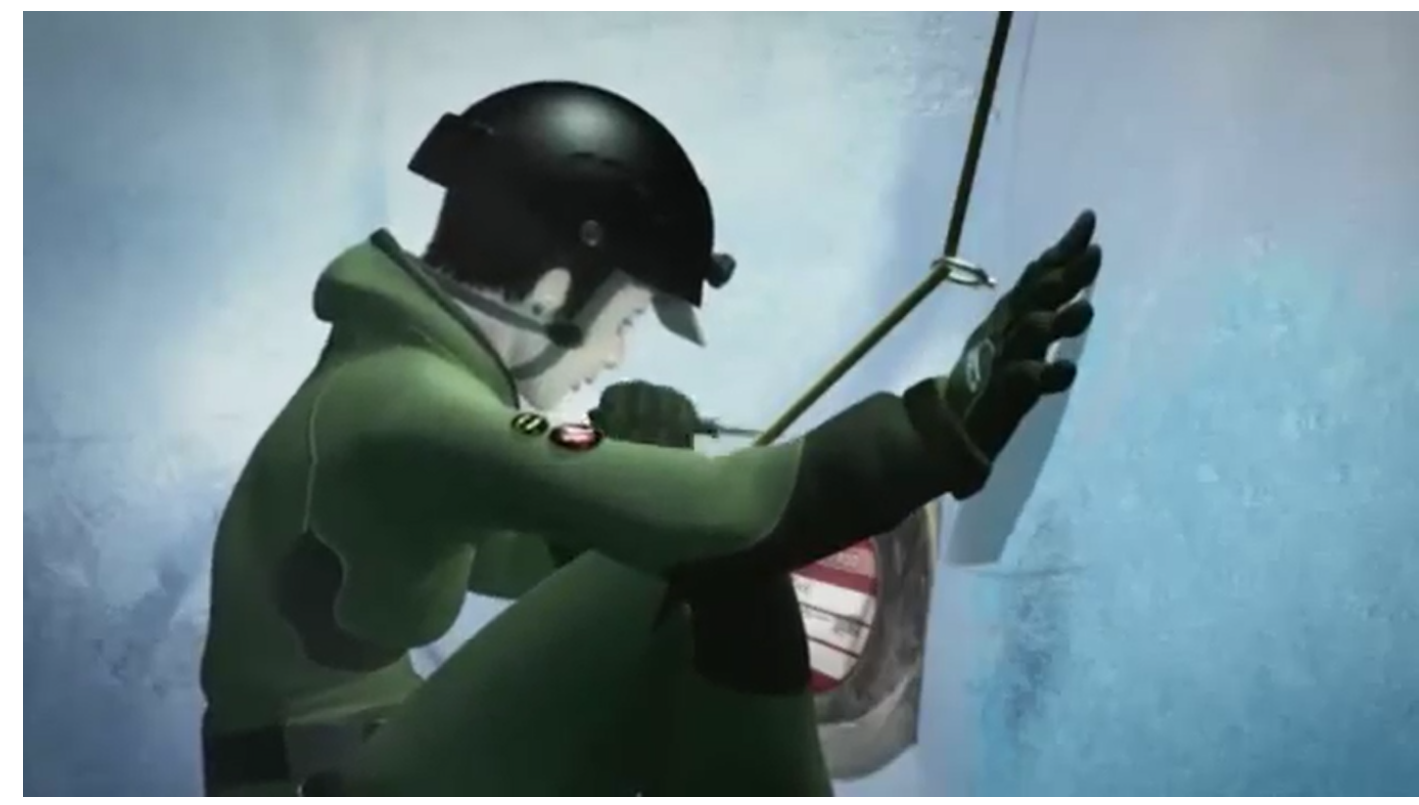

Figure 3. Scene from Stopmo (France, 2008).

intelligence, insanity, etc. - with new elements, such as the presence of a young inventor and curious girl, who is the only one able to make the experiment of her scientist father work (see Figure 4). The way the character Emilie defies the role traditionally attributed to women resembles Luna's character from O Show da Luna (Earth to Luna!), similar to the one discussed by de Oliveira and Magalhães [2017].

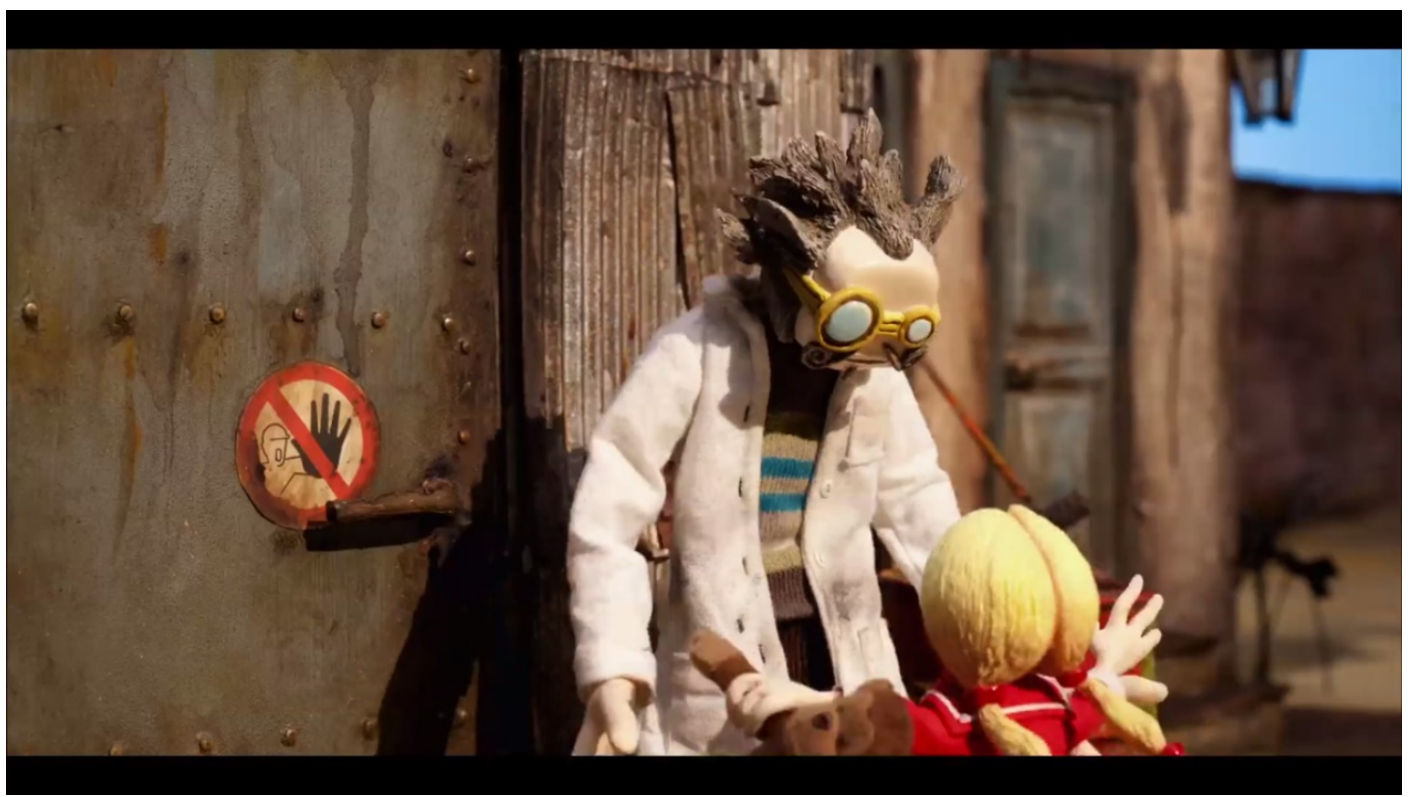

Figure 4. Scene from Emilie (Luxembourg, 2012).

Made in stop motion of paper dolls, the musical animation Miss Todd, directed by Kristina Yee, deals with the perseverance, determination and passion of Emma Lilian Todd in front of a male and excluding academic environment. Todd is considered the first woman to become an aeronautical engineer, design and build an airplane. The film begins with Todd, in her childhood, when she ventures to 
build prototypes of wings and birds. In one of her failed attempts, her grandfather tells her that even bird puppies must learn to fly, which encourages her to begin her readings on aeronautical science. Todd becomes a self-taught inventor and as an adult she is ready to enter college. However, she is welcome by mockery and refusals, and the doors to the world of academia remain closed to her because she is a woman. The scientist is welcomed by Olivia Page, who becomes her sponsor in building her own plane. In the film, Page's character promotes affirmative action by supporting women entering universities. While she is building her plane on her own in a dismissed shed, Todd sings the theme song from the movie, which among other things says that she will make her own wings and no one will stop her. Emma tries to get a pilot's license, but yet again her wish is denied. She registers her prototype airplane for a competition, but who is going to fly it is the French pilot Didier Masson, who tells her: "You look so sad, Miss Todd, it takes a man to hold a machine" (see Figure 5). Todd then rises up in protest, gags the pilot and assumes control of the flight dressed like a man. Her plane is the only one to take off in the competition and, for a moment, she feels fulfilled. However, when she lands, who is applauded is Didier Masson. One of the guards who inspected the flight identifies that who was flying was Miss Todd, nevertheless, he comments: "I think we both know it's impossible, Miss Todd, women do not fly."

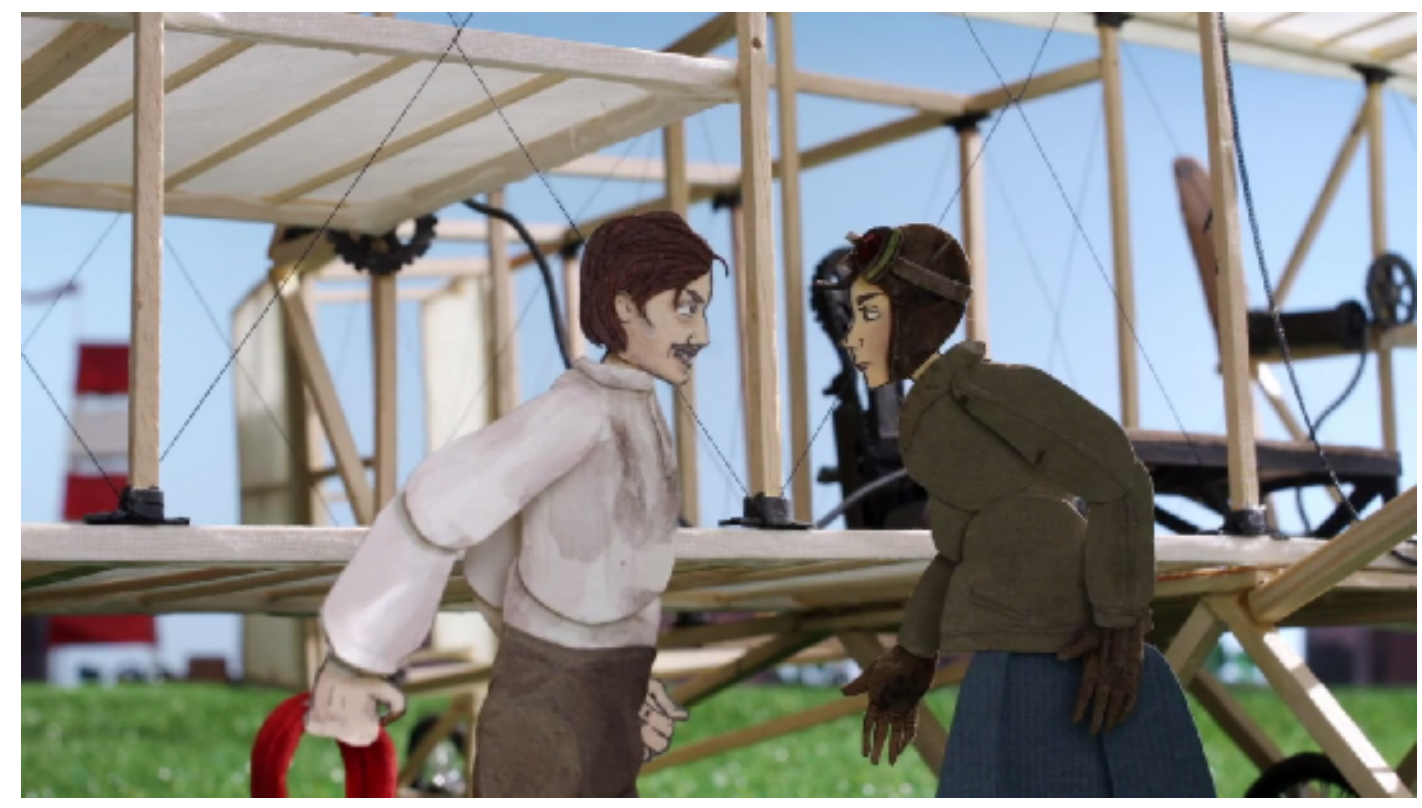

Figure 5. Scene from Miss Todd (United Kingdom, 2013).

Multi-award winner, Miss Todd received a gold medal for the Students Academy Awards in the foreign film category in 2013 - which had never been conferred to an animated film in this category. The exclusion of women from scientific practices and institutions, as shown in the representation of the aeronautical engineer Emma Todd in the film Miss Todd, is discussed by Maria Margaret Lopes [2006] when dealing with studies on gender and science from the point of view of history of science. The author writes about the growing discussion and theoretical deepening that have been taking place in the last four decades regarding the underrepresentation of women in science, focusing on the role that the representation of scientific knowledge, treated as objective and neutral, plays in the construction of the concept of what is natural/nature and what is cultural/social. 
Important scientific institutions have historically prevented women from being admitted. Examples of this are the Accademia dei Lincei, whose founder, Federico Cesi (1585-1630), forbade the entry of women into the institution, considering that they would represent a dangerous "distraction" from the task of unveiling the natural world and the French Academy of Sciences in Paris, that refused to admit the mathematician Sophie Germain (1776-1831) and vetoed Marie Curie (1867-1934) in the 20th century [Biagioli, 1995].

In Miss Todd as well as in Balinhas Maravilhas [Little Wonders] (Orlando Ávila Jr. and Vitor Peixoto, Brazil, 1999-2000), the female scientist-villain is dressed as a male character and only reveals her identity at the end of the short film. In both films, at times when the characters need to affirm their achievements, they appear to be taking the male identity. The sudden change of gender and sex attributes positive value and normality to the man and negative value to the woman.

In Laboratório espacial do barulho [Space Noise Laboratory] (Rubens Caetano Cunha Maciel, Brazil, 2008), several characters live inside a spaceship, which travels to the Earth to collect an apple seed and generate food inside the spacecraft. The anthropomorphized scientist character wears a short, attractive-looking dress. Body care in association with female beauty standard are issues addressed in the film. In one scene, one of the crew is watching porn scenes. When the food machine stops working and threatens to destroy the spacecraft, the female scientist and other characters are mesmerized by a TV programme on body and workout.

Sexist foundations in animated films
Gender issues also appear in films where the female characters are the interlocutors of the male scientist, as in Homem Planta [Plant Man] (William Paiva and Pedro Severien, Brazil, 2011), Dr Grordbort Presents: The Deadliest Game (James Cunningham; New Zeland, 2012) and The Bomb (sixxx legs) (Eddie White, Australia, 2003). In The Bomb (sixxx legs), a pervert male scientist observes an erotic show performed by bees inside a matchbox through the lenses of his microscope and has an erection at the end of the show, represented by the pouring out of liquids from a laboratory glassware (Figure 6).

In the initial scene of Homem Planta [Plant Man], the scientist's female assistant — named "Sexy Nurse" — looks like the plant man (see Figure 7), a half-human and half-plant creature, the result of a scientific experiment carried out in partnership with the "Corrupt Minister" from the Interação do Agrossocial [Agriculture-society Interaction], who publicly intends to resolve environmental issues, but meets the eccentric and greedy wishes of the "Alcoholic Scientist". One of the central characters in the story, the "Sexy Nurse", is represented by a young, blonde woman wearing provocative clothes who goes through the dilemma between being the man's mother plant and living a loving relationship with him. She is an abusive relationship with the "Insecure Male", who attacks the plant man and causes him to commit suicide.

In Dr Grordbort Presents: The Deadliest Game, the female character engages with a scientist exploring an unexplored environment aboard his expedition vehicle. The explorer constantly speaks about his deeds and merits while the interlocutor lacks any interest in the monologue. While she shows interest in the creatures they 


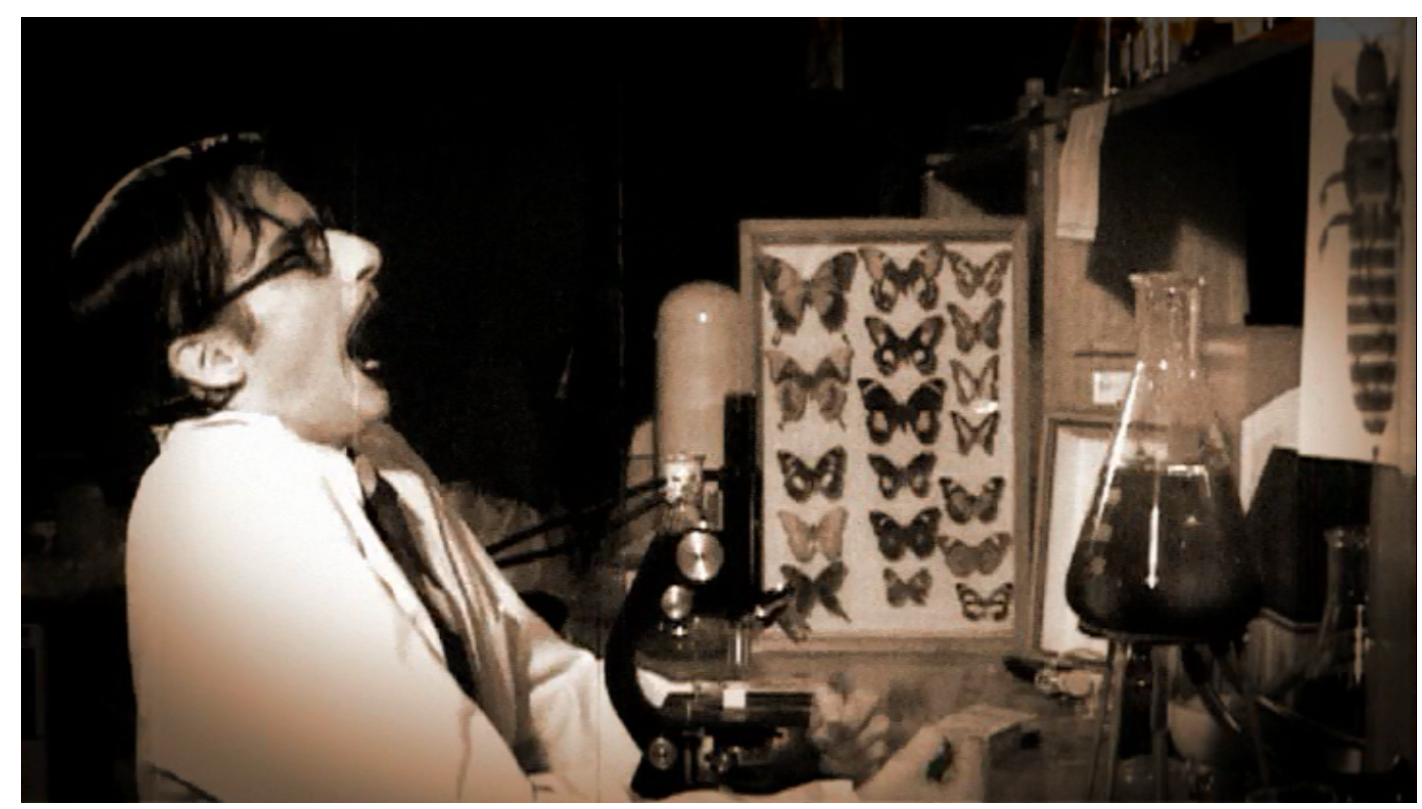

Figure 6. Scene from The Bomb (sixxx legs) (Australia, 2003).

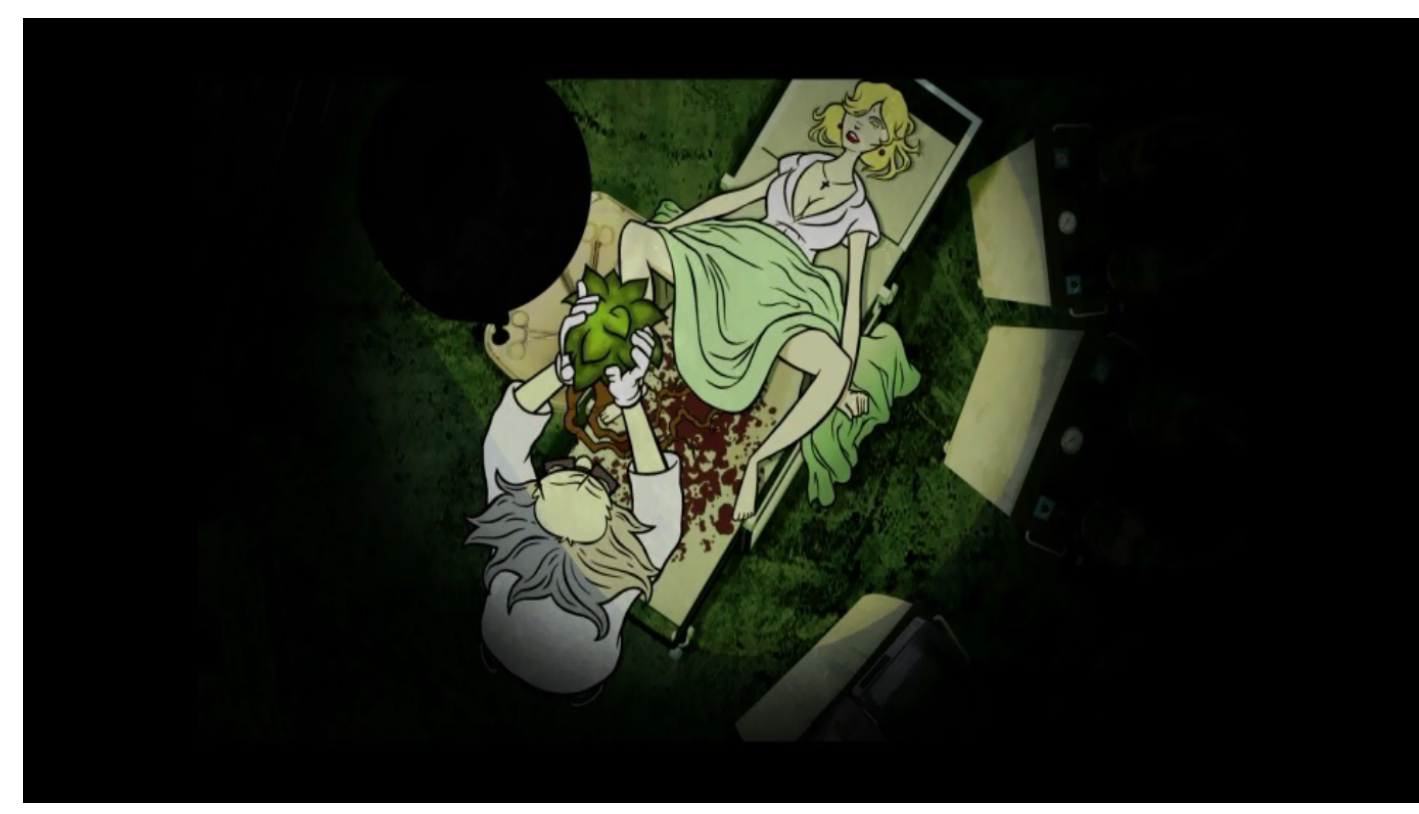

Figure 7. Scene from Homem Planta (Brazil, 2011).

encounter along the way, the explorer prides himself on exterminating them with his weapon.

\section{Conclusions}

This article aims to present an analysis of animated short films, in the field of author animation, that establish a dialogue with the discussions about gender and science. We analysed the representation of female scientists in a corpus of 102 films selected from the Anima Mundi festival that deal with science topics. We observed that female scientists lack visibility, being present in just $10 \%$ of the analysed films, a fact that is also corroborated in other studies [Chimba and Kitzinger, 2010; Long 
et al., 2010; Whitelegg et al., 2008]. On the one hand, the reduced presence of women in science films follows the trend of the festival itself, which gives women little voice and role in audiovisual production over more than two decades [Prado, 2017]. On the other hand, this data stands out from the Brazilian scenario, where the scientific community presents men and women researchers in similar proportions since 2010. ${ }^{3}$ According to the Estatísticas de Gênero: indicadores sociais das mulheres no Brasil 2018 [Gender Statistics: social indicators of women in 2018 Brazil] [IBGE, 2018], women reach, on average, a higher level of education than men, being the biggest difference in higher education. In the context of Latin America and the Caribbean, in 2018 women represented $45.4 \%$ of the total number of employees working in Research \& Development [UNESCO Institute for Statistics (UIS), 2018]. Regarding race, black female researchers remain the most excluded. ${ }^{4}$ This scenario is exarcebated by the low presence, or even absence, of black male scientists and black female scientists in media representations. In our analysis, there are no films with female black scientists.

We identified a reconfiguration of the gender stereotype in films such as Stopmo (France, 2008), Miss Todd (United Kingdom, 2013), Emilie (Luxembourg, 2012) and Rocket Science (United States, 2006), where women play an active role, gaining their space and visibility, in line with the changes in the gender roles described in literature [da Silveira Jr. and Prado, 2017]. Having identified that characteristics such as 'intelligent', 'dominant' and 'respected' are associated with most of the female characters is important in this list of films and highlights a different result from what is found in literature in regards to the representation of female scientists in films [Long et al., 2010; Steinke et al., 2011].

There are films that portray the exclusion of women from scientific practices and institutions, such as Miss Todd (United Kingdom, 2013) and films that reconfigure the image of women as protagonists of scientific practice, as in Emilie (Luxembourg, 2012). We also analysed the sexist foundations in the relationship of male scientists with their female interlocutors as in The Bomb (sixxx legs) (Australia, 2003) and in Homem Planta [Plant Man] (Brazil, 2011), which reinforce the consolidation, validation and reproduction of sexist stereotypes and heteronormative.

We highlighted the potential of this list of films as aesthetic and political experience in educational spaces, both in formal and non-formal education. Fresquet \& Migliorin highlight the transformative potential of cinema in school over educational practices, where "it is possible to create ways of seeing and being in the world that can disrupt a given order, of what is established, of places of power" [Fresquet and Migliorin, 2015, p. 8], highlighting the critical, political and subversive role of cinema as a pedagogical practice. The mapping of Brazilian films carried out in this research may also contribute to create the space expanded by Law 13.006/14 of 2014 - which obliges all primary schools to show two hours of national cinema per month as an additional curricular component - integrated with the pedagogical proposal for schools [see Fresquet, 2015].

\footnotetext{
${ }^{3}$ See CNPq, Pesquisadores por sexo [CNPq, Conselho Nacional de Desenvolvimento Científico e Tecnológico, 2019].

${ }^{4}$ See CNPq, Negros e Negras nas áreas do conhecimento e faixa etária [CNPq, Conselho Nacional de Desenvolvimento Científico e Tecnológico, 2015].
} 
The representations of gender and science in O Show da Luna (Earth to Moon!) and its potential for the teaching of science analysed by de Oliveira and Magalhães [2017] highlight how the animations allow one to question stereotyped concepts about science and to promote the discussion about the history of women in science. The authors emphasise the presence of a girl protagonist, who does not wear a lab coat nor glasses and does not appear in a laboratory: "according to her there are many things to discover everywhere" [de Oliveira and Magalhães, 2017, p. 116]. Inocêncio and Oliveira [2015] analyse how the drawings approach the making of gender meanings and affirm the importance of animations in the representation of diversity. The exhibition of films that establish a dialogue with gender issues can contribute to the search for an education that can contemplate diversity and be a space for questioning the homogenous and normative formats.

Translated by Sabina Brusemini

References

Anibal, A. F. and dos Santos, M. R. A. (2016). 'A desconstrução dos estereótipos de gênero na animação Hora de Aventura: Uma análise multimodal da personagem Princesa Jujuba'. In: Anais do Intercom - Sociedade Brasileira de Estudos Interdisciplinares da Comunicação, XVIII Congresso de Ciências da Comunicação na Região Nordeste. Brazil.

Biagioli, M. (1995). 'Knowledge, freedom and brotherly love: homosociality and the Accademia dei Lincei'. Configurations 3 (2), pp. 139-166. https://doi.org/10.1353/con.1995.0010.

Calvert, S. L., Kotler, J. A., Zehnder, S. M. and Shockey, E. M. (2003). ‘Gender stereotyping in children's reports about educational and informational television programs'. Media Psychology 5 (2), pp. 139-162. https://doi.org/10.1207/s1532785xmep0502_2.

Calvert, S. L., Murray, K. J. and Conger, E. E. (2004). 'Heroic DVD portrayals: what U.S. and Taiwanese adolescents admire and understand'. Journal of Applied Developmental Psychology 25 (6), pp. 699-716. https://doi.org/10.1016/j.appdev.2004.09.004.

Chambers, D. W. (1983). 'Stereotypic images of the scientist: The draw-a-scientist test'. Science Education 67 (2), pp. 255-265. https://doi.org/10.1002/sce.3730670213.

Chimba, M. and Kitzinger, J. (2010). ‘Bimbo or boffin? Women in science: an analysis of media representations and how female scientists negotiate cultural contradictions'. Public Understanding of Science 19 (5), pp. 609-624. https://doi.org/10.1177/0963662510377233.

Citelli, M. T. (2000). 'Mulheres nas ciências: mapeando campos de estudo'. Cadernos Pagu 15, pp. 39-75. URL: https://periodicos.sbu.unicamp.br/ojs/index.php /cadpagu/article/view/8635362.

CNPq, Conselho Nacional de Desenvolvimento Científico e Tecnológico (2015). Negros e Negras nas áreas do conhecimento e faixa etária. URL: http: //www.cnpq. br /documents/10157/3a9238af-57b3-47a9-ba79-514a633f7223.

- (2019). Séries históricas por pesquisadores por sexo, diretório dos grupos de pesquisa do Brasil. Brazil. 
da Silva Mesquita, N. A. and Soares, M. H. F. B. (2008). 'Visões de ciência em desenhos animados: uma alternativa para o debate sobre a construção do conhecimento científico em sala de aula'. Ciência \& Educação (Bauru) 14 (3), pp. 417-429. https://doi.org/10.1590/s1516-73132008000300004.

da Silveira Jr., P. M. and Prado, L. M. (2017). 'Desenhos Animados e Representação Feminina: uma trajetória em produções brasileiras'. Sessões do Imaginário 22 (38), p. 130. https://doi.org/10.15448/1980-3710.2017.2.28955.

de Oliveira, L. R. and Magalhães, J. C. (2017). ‘Esse é o show da Luna: investigando gênero, ensino de ciências e pedagogias culturais'. Domínios da Imagem 11 (20), pp. 95-118. https://doi.org/10.5433/2237-9126.2017v11n20p95.

Duarte, R. (2002). Cinema \& educação: refletindo sobre cinema e educação. Belo Horizonte, Brazil: Autêntica.

Fresquet, A., ed. (2015). Cinema e educação: a Lei 13.006: reflexões, perspectivas e propostas. Rio de Janeiro, Brazil: Universo Produção.

Fresquet, A. and Migliorin, C. (2015). 'Da obrigatoriedade do cinema na escola, notas para uma reflexão sobre a lei 13.006/14'. In: Cinema e educação: a Lei 13.006: reflexões, perspectivas e propostas. Ed. by A. Fresquet. Rio de Janeiro, Brazil: Universo Produção.

Graça, M. E. (2006). Entre o olhar e o gesto: elementos para uma poética da imagem animada. São Paulo, Brazil: Editora Senac.

Harding, S. (2007). 'Gênero, democracia e filosofia da ciência'. Revista Eletrônica de Comunicação, Informação e Inovação em Saúde 1 (1), pp. 163-168. https://doi.org/10.29397/reciis.v1i1.891.

Hoffner, C. (1996). 'Children's wishful identification and parasocial interaction with favorite television characters'. Journal of Broadcasting E Electronic Media 40 (3), pp. 389-402. https://doi .org/10.1080/08838159609364360.

Hoffner, C. and Buchanan, M. (2005). 'Young adults' wishful identification with television characters: the role of perceived similarity and character attributes'. Media Psychology 7 (4), pp. 325-351. https://doi.org/10.1207/s1532785xmep0704_2.

IBGE (2018). Estatísticas de Gênero: indicadores sociais das mulheres no Brasil.

Inocêncio, A. F. and Oliveira, M. A. (2015). 'Pedagogias queer em ação: personagens de desenhos, questões de gênero e noções de diferença'. Semina: Ciências Sociais e Humanas 36 (2), pp. 31-42. https://doi.org/10.5433/1679-0383.2015v36n2p31.

Kaplan, E. A. (1995). A mulher e o cinema: os dois lados da câmera. Rio de Janeiro, Brazil: Rocco.

Keller, E. F. (1978). 'Gender and science'. Psychoanalysis and Contemporary Thought 1 (3), pp. 409-433.

- (1987). 'The gender/science system: or, is sex to gender as nature is to science?' Hypatia 2 (3), pp. 37-49. https://doi.org/10.1111/j.1527-2001.1987.tb01340.x.

Long, M., Steinke, J., Applegate, B., Lapinski, M. K., Johnson, M. J. and Ghosh, S. (2010). 'Portrayals of male and female scientists in television programs popular among middle school-age children'. Science Communication 32 (3), pp. 356-382. https://doi.org/10.1177/1075547009357779. 
Lopes, M. M. (2006). 'Sobre convenções em torno de argumentos de autoridade'. Cadernos Pagu (27), pp. 35-61. https://doi.org/10.1590/s0104-83332006000200004.

Massarani, L., Castelfranchi, Y., Ramalho, M., Pedreira, A. E., Reznik, G. and Amorim, L. (2013). 'Gênero, ciência e TV: representações da mulher cientista nos programas brasileiros Jornal Nacional e no Fantástico'. In: XIII Reunión de la Red Pop, 2013, Zacatecas. Memorias de la XIII Reunión de la Red Pop. Zacatecas, Mexico: Red Pop e Museu de Ciencias de Zacatecas.

Meneses, V. D. (2017). 'Representações das gerações femininas na produção audiovisual infantil'. Revista Observatório 3 (6), p. 387. https://doi.org/10.20873/uft.2447-4266.2017v3n6p387.

Piscitelli, A. (2009). 'Gênero: a história de um conceito'. In: Diferenças, igualdade. Ed. by H. B. d. Almeida and J. Szwako. São Paulo, Brazil: Berlendis \& Vertecchia, pp. 116-149.

Prado, L. M. (2017). 'Anima Mundi: participação feminina na produção de animação'. In: Anais do II Congresso Internacional sobre Competências Midiáticas, pp. 476-483.

Reznik, G., Massarani, L. and Moreira, I. (2019). 'Como a imagem de cientista aparece em curtas de animação?' História, Ciências, Saúde - Manguinhos 26 (3).

Reznik, G. (2017). 'Imagem da ciência e de cientistas em curtas de animação'. Dissertação (mestrado). Brazil: Universidade Federal do Rio de Janeiro, Decania do Centro de Ciências Matemáticas e da Natureza, Programa de Pós-Graduação em História das Ciências e das Técnicas e Epistemologia. URL: https ://sucupi ra.capes.gov.br/sucupira/public/consultas/coleta/trabalhoConclusao/v iewTrabalhoConclusao $\cdot$ jsf?popup=true\&id_trabalho=5280920.

Schienbinger, L. (2001). O feminismo mudou a ciência? Bauru, SP, Brazil: EDUSC.

Scott, J. (1995). ‘Gênero: uma categoria útil de análise histórica'. Revista Educação $\mathcal{E}$ Realidade 20 (2), pp. 71-99.

Steinke, J. (2005). 'Cultural representations of gender and science: portrayals of female scientists and engineers in popular films'. Science Communication 27 (1), pp. 27-63. https://doi .org/10.1177/1075547005278610.

Steinke, J., Applegate, B., Lapinski, M., Ryan, L. and Long, M. (2011). 'Gender differences in adolescents' wishful identification with scientist characters on television'. Science Communication 34 (2), pp. 163-199. https://doi.org/10.1177/1075547011410250.

UNESCO Institute for Statistics (UIS) (2018). Women in science.

Whitelegg, E., Holliman, R., Carr, J., Scanlon, E. and Hodson, B. (2008). Invisible witness: investigating gendered representations of scientists, technologists, engineers and mathematicians on U.K. children's television. Report for the UKRC.

Authors

Gabriela Reznik is a biologist and a science communicator. She is a $\mathrm{PhD}$ student in Education, Dissemination and Management in Biosciences at the Federal University of Rio de Janeiro (UFRJ) with a Master degree in History of Sciences, Techniques and Epistemology (UFRJ), specialised in Public Understanding of Science, Technology and Health (Fiocruz). E-mail: gabirz@gmail.com. 
Luisa Massarani is a journalist and a science communicator. She coordinates the National Institute of Public Communication of Science and Technology in Brazil and the Master programme in Communication of Science, Technology and Health, created in 2016, at Oswaldo Cruz House, Oswaldo Cruz Foundation, Brazil. She is also a coordinator for the Latin America and the Caribbean section on SciDev.Net (www.scidev.net). Winner of the José Reis Prize for Science Communication in 2016 and the Jabuti Prize for Literature in 2017. E-mail: luisa.massarani@fiocruz.br.

\section{How to cite}

Reznik, G. and Massarani, L. M. (2019). 'Gender and science in animation: analysis of the Anima Mundi Festival films'. JCOM 18 (02), A08.

https://doi.org/10.22323/2.18020208. 